\title{
World Society as a Shared Ethnos and the Limits of World Society in Central Asia
}

\begin{abstract}
After the demise of the Soviet Union, the five Central Asian republics have struggled to maintain a degree of regional identity within the wider region of Eurasia by combining historical, religious and value-related discourses of commonality. In particular, 'the Central Asian people' has always been hailed as the 'glue' of this region, despite the fact that states in this area are following different political and economic orientations. Although 'Kazakhs, Kyrgyz, Tajiks, Turkmens and Uzbeks have lived for centuries together as brothers', as it is often heard in regional official statements, this 'regional world society' is being fractured by what I call the hyperinstitutionalisation of pluralist institutions of international society. Using an English School approach, this paper explores the detachment of the Central Asian international society from the Central Asian world society, and investigates into the role played by the institutions of the former in weakening the substance of the latter.
\end{abstract}

Keywords: Central Asia, regional international society, regional world society, authoritarianism, nationalism, hyper-institutionalization.

Author: Filippo Costa Buranelli, University of St. Andrews

Address: Room 024, School of International Relations, Arts Building, The Scores, St Andrews, Fife, KY16 9AX, Scotland, UK

Email: fcb7@st-andrews.ac.uk

Bio: Filippo Costa Buranelli is Lecturer in the School of International Relations at the University of St Andrews, UK. Prior to this, he was Teaching Fellow and Research Associate at King's College London and UCL. His research interests include IR theory (especially the English School), global governance and international organizations, regionalism and area studies, with a strong focus on Central Asia and the post-Soviet space. His research has been published in Millennium: Journal of International Studies, Global Discourse, and the Journal of Eurasian Studies. He is currently working on a project on authoritarian solidarism in international society.

Word count: 7,498 (excluding this page) 


\section{Introduction}

With the aim of contributing to the regional agenda of the English School of International Relations (henceforth ES) and to recent engagements with the notion of 'world society', this paper discusses the existence of a Central Asian world society within the context of a Central Asian international society. Specifically, this paper is not concerned with the existence of a Central Asian world society only, but also with how and whether the alleged Central Asian world society interacts, affects and is affected by the Central Asian international society in any meaningful way.

The argument presented here is that Central Asia is an interesting case of a regional international society suppressing a regional world society. This, as will be clarified and discussed more in depth below, has to do with what I call the 'hyper-institutionalization' of given practices of international society, namely sovereignty, nationalism and patrimonial market economy/capitalism. By hyper-institutionalization, I mean a degree of institutionalization of practices of international society to a level such to limit the participation of non-state actors to the 'game' of international society itself.

By relying on archival documents, élite interviews and observations conducted during fieldwork in Central Asia, the paper proceeds as follows. The first section defines the two key terms of this paper, i.e. world society and Central Asia. The second section offers an overview of how world society in Central Asia has developed in history, and how it has always been dynamic and thriving by blending historical, cultural, religious and ethnic commonalities, identities and allegiances. The third section juxtaposes these discourses and practices of the Central Asian world society, revamped after the collapse of the Soviet Union, with the developing Central Asian international society, highlighting loci of friction, opposition and adversarial dynamics between the two domains. The penultimate section focuses on those elements of the Central Asian world 
society that are resisting the hyper-institutionalization of international society in the region, while the final section concludes the paper and presents avenues for further research.

\section{Definitions of key terms}

As Barry Buzan nicely put it, world society has often been considered as an ontological Cinderella at best (2004, p.11) and an analytical dustbin at worst (2004, p. 44). Therefore, whether identified 'as an analytical dustbin, as chronically underdeveloped, or as an area that the New English School needs to push into' (Pella 2013, p. 66), the need for more ontological and analytical precision is still felt.

Within the ES, two are the main understandings of world society (Pella, 2013). The first one refers to a 'classical understanding', based on cosmopolitan and Kantian ideas relying on the primacy of the individual over states in world politics matters. It is a conceptualization of world society that emphasizes linkages, liberal norms and values shared by humanity tout-court in the attempt to transcend the divisive nature of the state system and forge ties across peoples across the globe. It is called 'classical' as it was first conceptualized and developed by members of the British Committee of International Relations and early ES thinkers. Both Martin Wight (1966) and Hedley Bull (1977, p. 279) accorded importance to the human dimension of international society, and their thinking was later adopted by John Vincent (1987) and Ian Clark (2007), too.

The second one, conversely, refers to the 'new ES' and specifically to Buzan's concerns with analytical/taxonomical clarity and terminological precision, as well as with what may be called a 'normative dissatisfaction' with the overly cosmopolitan tone of the classical understanding of the term. For him, 'world society' is to be broken down into two different ontologies, a 'non-state actors' one and an 'inter-human' one (2004, p. 127) due to fundamental 
methodological differences in studying the two (societies, groups and individuals are studied in different ways, so aggregating them under a single 'world society umbrella' would be methodologically untenable). Yet, given Buzan's interest in analytical clarity, following this distinction we know less about the 'normative content and function' of world society.

Given my interest in exploring the interaction between (regional) international and world society, in this paper I rely on Ian Clark's definition of world society, linked somehow to the classical understanding of it but less normatively connoted: 'The realm of the individual, of the non-official group or movement, and of the transnational network of nongovernmental agents' (2007, p. 6).

I adopt this reading of 'world society' because of several reasons. First, I am more interested in state-society relations in Central Asia than with analytically defining a regional world society. Second, because being at the regional level one may focus on the human level without being necessarily cosmopolitan or Kantian: not all regions hold liberal values. Third, the distinction between groups and individuals holds less in Central Asia than in other places. In this region, as recent scholarship has noted, the primacy of the 'collectivity' over 'the individual' has always been a landmark in politics, society and culture (Collins, 2006). Yet, differently from Clark I aim to show how international society in the region has tamed and weakened world society. The logic of the present inquiry is therefore the reverse of his.

Defining Central Asia is certainly not easy, too. This geographical concept, simple to define only in appearance, has been contested and opposed in many ways and with many motivations, and it is frequently subject to semantic re-negotiations (Sahadeo and Zanca, 2007).

In the literature, it is frequent to see 'Central Asia' uncritically used as a synonym with the five republics of Kazakhstan, Kyrgyzstan, Tajikistan, Turkmenistan and Uzbekistan (see, among 
others, Mandelbaum, 1994; Gleason, 2001; Abdullaev, 2002; Burnashev, 2002; Polat, 2002; Rahimov, 2007; Pomfret, 2010; Cummings and Hinnebusch, 2011; Kavalski, 2012), listing as common factors economic transition from centralised to market-driven mechanisms, ethnic tensions, environmental degradation, presence of Islamic and Soviet traditions and authoritarianism as a general method of rule as regional characteristics.

Furthermore, in her admirable treatment of the slippery notion of Central Asia, Sally Cummings argues that 'in contemporary usage the Central Asian, Russian and English understandings of the term more often than not refer to the five independent republics' (2012, p. 2).

I am aware of the several differentiations that Central Asia can have in social sciences (see e.g. Volovoj, 2009; Lewis, 2008; Amineh and Houweling, 2005). Yet, drawing on recent emic ES work on the region (Costa Buranelli, 2015), in this paper I adopt the conventional, political definition of Central Asia as comprising the five Muslim post-Soviet republics of Kazakhstan, Kyrgyzstan, Tajikistan, Turkmenistan and Uzbekistan.

\section{The Central Asian world society in history}

Central Asia has always been a fertile place for the development of a world society as meant above. As has been noted,

[t]he political units that were formed in medieval Central Asia $[\ldots]$ were built on dynasties whose tribal legitimacy transmogrified into dynastic legitimacy reinforced by the claims to religious authority. The identities of the populations that fell under the dynastical rule never coincided with 
administrative or cultural-linguistic boundaries but consisted of the mixture of such features as loyalty to a local leader or khanate, geographic affinity to a certain city or region or region, nomadic or sedentary lifestyle, membership in an Islamic community, and a sense of kinship (Omelicheva, 2014, p. xii).

Analytically, we can observe several facets of the Central Asian world society in history, based on different identities and allegiances. First of all, one may speak of a nomadic world society and a sedentary one, each with its own customs, rules, norms and habits but also intertwined and capable of interact, constituting an interactive social 'symbiosis' (Levi 2007, p. 16; Costa Buranelli, 2014).

Furthermore, one may argue that another form of world society in the past of the region was the Ummah, or brotherhood among Muslim peoples. As a matter of fact, the Central Asian polities, albeit largely independent, were formally part of the Ottoman Empire, and recent archival work has showed how they felt part of the wider Islamic family rather than having affiliation to their territory strictu sensu (Costa Buranelli, 2014).

A third way in which a world society could be seen at play in Central Asia is that of a Turkic community, i.e. the feeling of belonging to the wider community of Turkic populations. This has to do with the lineage from the heirs of Gengis Khan and Timur in the XII and XIII centuries, when Turkic tribes invaded the Central Asian lands. Quite interestingly, elements of this ethnic conceptualisation of world society can still be found in the linguistic realm (Turkmen, Kazakh, Kyrgyz and Uzbek resemble Turkish as an idiom in different degrees), and in the existence of some multilateral international organisation aimed at fostering cultural and ethnic bonds between Turkic countries (a good, institutionalized example can be the TÜRKSOY, the 
association of Turkic-speaking states comprising Turkey, Azerbaijan, Kazakhstan, Kyrgyzstan, Turkmenistan and Uzbekistan).

But this is not the end of the story. Immediately after the Communist Revolution, Turkic elements of the Central Asian world society conflicted with Bolshevik rule. It should be remembered that exactly because of pan-Turkic elements in the first decades of the XX century the Soviet rulers decided to create nation states in Central Asia, drawing the boundaries of the would-be Autonomous Soviet Socialist Republics of Kazakhstan, Kyrgyzstan, Tajikistan, Turkmenistan and Uzbekistan. Muslim modernist intellectuals such as the Jadids at the end of the XIX century and Enver Pasha in the early 1920s were fuelling and eliciting pan-Turkic sentiments paired with Islam exactly to create a supranational polity ('Turkestan') based on ethnic, historical, cultural and linguistic as well as religious grounds (Levi 2007, p. 7).

\section{The contemporary Central Asian world society}

At the end of the Cold War, when the Central Asian Autonomous Soviet Socialist Republics were about to become fully independent states, a regional world society with an identity based on common ethnic, historical and cultural traits was developing and being revamped again. Yet, this world society was not meant to be Revolutionist as in pre-Soviet times, or in the very early Soviet times as we saw with the example of the Jadids, but rather to go hand in hand with an embryonic society of independent states based on the institutions of sovereignty, international law, diplomacy and balance of power (Clark 2007, p. 22).

As a matter of fact, at a meeting held in Alma-Ata on 22-23 June, 1990 the leaders of the

Central Asian republics denied having made the first step toward a confederation despite the persistence of discourses revolving around ideas of 'Turkestan'. Presidents Nazarbayev of 
Kazakhstan, Karimov of Uzbekistan and Mahkamov of Tajikistan confined the significance of the meeting to promoting cooperation, emphasizing the sanctity of existing borders. Mahkamov said that 'a united Turkestan was out of the question'. 1

In the same period, there was another meeting, this time listing independent movements and organisations from the republics, in the format of a conference aimed at bringing the newly independent regional states together, even if not in a confederational form. The only republic not represented was Turkmenistan, due to clashes between the delegates off to Alma-Ata and the police (Goble, 1990). During the conference, participants discussed ways to reduce inter-ethnic conflicts in Central Asia, particularly the fight over land between the Kyrgyz and the Uzbeks in the Osh region (Kyrgyzstan), sought to improve cooperation between organizations in the different republics and regions of Central Asia and adopted an 'Appeal to the Peoples of Turkestan'.

The 'Appeal' emphasised the common ethnic, linguistic, and cultural background of the peoples of Central Asia, significantly referred to as 'Turkestan', and called for them to cooperate in search of a better future for the region. This was only the first attempt of many to elicit a 'regional consciousness' at the level of peoples and to develop inter-human ties across the Central Asian republics. What follows is a series of events during which international and world society went hand in hand in the construction of a regional order.

On 7 January, 1993, when regional leaders discussed the creation of the first Central Asian international organization ('Central Asian Union') for the first time the adjective 'brotherly' was used to describe relations between states and peoples of the now independent Central Asian republics. ${ }^{2}$ On 22 January, 1993 Uzbek President Islam Karimov stated at an official meeting that 'traditional neighbours, which share a common culture, tradition, language, will go their way [with respect to other post-Soviet countries]'.3 On 26 March, 1993 there was the first international 
conference on the problems of the Aral Sea in Kyzyl-Orda, Kazakhstan, with the participation of civil society actors, demonstrators and local environmental NGOs from all over the region in an attempt to socialize the governments of the region to address environmental problems in a cooperative, solidarist way given that the interests of the 'Central Asian people' were at stake. ${ }^{4} \mathrm{On}$ that day, it is important to note, the five Central Asian countries founded the International Fund for Saving the Aral Sea. On 31 October - 1 November, 1995, a letter authored by Turdakun Usubaliyev, MP of the Kyrgyz Republic, addressed to Uzbek President Karimov, Kazakh President Nazarbayev and Kyrgyz President Akaev and titled 'How to divide the souls of the peoples [in Central Asia] with boundaries?' was published in the pages of 'Slovo Kyrgyzstana', one of the most prominent daily newspaper in Kyrgyzstan at that time. ${ }^{5}$

In this letter, the author explored numerous topoi of the world society in Central Asia: 'Our peoples have never been indifferent to each other. Uzbeks, Kazakhs, Kyrgyz, Tajiks and Turkmens have lived for centuries as neighbours and brothers. Can we forget that our peoples have much in common in their history, way of living, traditions and customs, great similarity of material and spiritual culture and language?'. And also, 'why not adopt a past history of what is useful and necessary for modern life of our peoples, that unites and strengthens their fraternal unity?'

Noting the increasing role of the states in the region and the expenses of peoples, due to emphasis on the newly acquired sovereign character of the republics a d demarcation of borders for security needs (Dadabayev, 2012), Usubalyiev argued that

in recent years, exclusionary political choices destroyed centuries that existed between our peoples' kindest relationships, mutual support in their life. We seem to have forgotten that our people live in the same space. God 
himself told us that people are not alienated from each other, along with high efficiency to extract the mutual benefit of the rich natural resources of our region. We are talking not about the interests of one nation, but for the safe, prosperous life for the peoples of our countries.

In 1996 and 1997 there was a new impetus for the Central Asian world society and regional organic solidarity among people. Forums of Central Asian intellectuals on Manas (the Kyrgyz epic hero) and the publication of the magazine 'Turkestan: Our Common Home' were launched. On 18-19 July 1997, the Issyk Kul Forum of Intellectuals was instructed to create a Central Asian 'paradigm of development' - based on peace, agreement and tolerance, 'human synthesis of cultures in favour of the nations' and 'religious and civilizational tranquillity among cultures'.

In autumn, a new forum of intellectuals and exponents of civil society ('Forum of Central Asian Culture') was launched, where it was demanded that processes of inter-state regionalism and pursuance of different national interests should have been reconciled on the basis of 'peace, harmony and agreement' between the peoples. In this respect, Kyrgyzstan launched the magazine 'Central Asia and the Culture of Peace', and it was stressed that the regionalization of this idea could have been a factor of integration and stability. ${ }^{6}$ One thing to notice in all these regional experiments is that they were all framed as 'Central Asian' or as 'Turkestan', thus echoing memories of pristine commonalities and shared identities that were dealt with above and somehow disproving the notion that 'Central Asia' was and is a 'myth' (Olcott, 1994).

On 30 November, 1999 a double interview with the poet Chingiz Aitmatov, Kyrgyzstan's most prominent intellectual, and Osmonakun Ibraimov, a Kyrgyz diplomat, appeared in the local press. ${ }^{7}$ In it, it was mentioned the necessity for an 'Assembly of a Turkestan Culture', or 'Assembly of the cultures of the peoples of Central Asia', and both stated how 'Bishkek is familiar and dear 
to me as Tashkent or Almaty, and I can say the same for Tajikistan or Turkmenistan' emphasizing the pervasive regional approach to peace and stability, common mentality and affection to land. ${ }^{8}$

Yet, for all this appeals, initiatives coming from non-state actors to sustain Central Asian 'regionness' and to enhance inter-state integration have become fewer and fewer. The phase in which the Central Asian world society finds itself in this historical period, and especially in the 2000s in the light of the systemic changes occurred after 9/11, the Afghan conflict and the process of consolidation of authoritarian rule in the region is one of control and discipline from above thanks to the hyper-institutionalisation of practices that were not known before independence.

\section{Sovereignty}

In the Soviet Union, internal borders were simply administrative and did not have the kind of control procedures associated to sovereign prerogatives. With the establishment of five independent republics in Central Asia, fully subjects of international law, borders became from administrative to being juridically controlled by the respective capitals. In other words, space became territory (Reeves, 2014).

With particular respect to zones such as the Ferghana Valley, the most densely populated area in Central Asia where the territories of Uzbekistan, Kyrgyzstan and Tajikistan intersect, the introduction of border control and delimitation/demarcation (still ongoing) has interfered with and disrupted still persistent nomadic or semi-settled ways of organising political life and community, as well as transboundary, communal settlements, creating incidents and skirmishes along the border and in the several enclaves constellating the region (e.g. Vorukh, Sokh). In some segments, such as certain areas along those between Kyrgyzstan and Uzbekistan and Uzbekistan and Tajikistan, barbed wires and walls make this hyper-institutionalization visible. In other parts, 
though, the hyper-institutionalization consists in extreme sanctions for violating each other's sovereignty: people are killed along these borders. Usually it is border guards firing on alleged trespassers, but for villagers in these areas it is often unclear where the border actually is (RFERL 2016).

Sovereignty and its derivative of border control and border management in their hyperinstitutionalised form have prevented a Central Asian world society to prosper and flourish along smooth lines. Notwithstanding the fact that all Central Asian states have signed and ratified the Commonwealth of Independent States document on freedom of movement on the territory of the organization, Uzbekistan and Turkmenistan have strict visa regimes with other regional states such as Tajikistan due to 'national security' reasons, with Turkmenistan often closing its borders with neighbouring countries without any prior notice. Furthermore, Uzbekistan has still an exit-visa regime for its citizens, thus making more difficult the establishment of transnational linkages with other Central Asian states.

These protective measures, it has been argued (Dadabaev, 2012, pp. 557-558), have been due, in the words of governmental officials, to the possible exodus of refugees into territories of neighbouring states and uncontrolled migration as exemplified by the Afghan and Tajik scenarios or the more recent ethnic cleansing of Uzbeks in Kyrgyzstan, the rise in religious extremism and border crossing by the members of terrorist organisations, free drug-trafficking and the limited capacity (and political will) of Central Asian states to control this across transparent borders, scarcity of natural resources and fierce competition for water, gas and oil among regional nation states. Furthermore, the transformation of the Central Asian Autonomous Soviet Socialist Republics into sovereign entities with legally defined borders disrupted also ancient, rooted 
communal, trans-territorial and group-based arrangements of managing water resources, thus creating frictions and rivalries in the region as noted above (Benvenisti, 2008).

In an interesting conversation I had with a high-ranking diplomat in Kazakhstan, conversation that can be read as a tribute to Bull's conceptualization of international society, I was told that Central Asian states

have started building up barbered-wired borders. Why? Because otherwise people and animals would cross territories messily. You may think that if we are putting up such borders, we are distancing ourselves, but it's not like that, the erection of borders is to bring order, because if a sheep crosses the border, then the shepherd runs after it and then violates somebody else's territory, and the custom person would just shoot him, you know? Order is especially needed (2014, personal communication).

Another prominent Uzbek political scientist, Farkhad Tolipov (2007, p.21; 2015), has commented on the relationship between the newly imposed international society over the much older and robust Central Asian regional world society:

The issue of national and regional identity is a very important issue for the people of the Central Asian region. When apologists of the economic determinism of regional integration advance their arguments in order to prove the failure, or premature, integration of Central Asian states (in view of their economic differences) they certainly do not pay attention to one fundamental fact: that their rationalism of economic conditionality to 
integration is applicable to the case of full-fledged state formations, of preindustrial and industrial epochs. In our case, given the universal tendency towards a regionalization of international relations, there is an incompleteness to the process of political cartography in Central Asia. There is an insurmountable obstacle to its completion, which was historically formed by a transborder way of life for the inhabitants there, for whom national identity does not conform to the imposed international borders. But there is also an economic irrationality to delimitation.

The irony here is that while ES theory has theorized borders as tools to provide order and enhance tolerance and diversity (Williams, 2002, 2005), they can also lead to conflict, for 'the history of transnational and translocal interrelations has not rendered the border as a frontier on the local populations' mental maps' (Kuzmits, 2013, p. 338 quoted in Matveeva, 2017, p. 14). ${ }^{9}$

Erlan Abdyldaev, former foreign minister of Kyrgyzstan, indirectly stressed how sovereignty and borders have strongly demarcated regional countries detaching them from each other, thus reducing contacts and fragmenting world society actors (2008):

People that were born after 1992 know what the United States and China are, they know more of what Europe is but know less about Kazakhstan. Now more students study in China. Before we were acquiring knowledge in Almaty, Kazakh students were studying here and relations between relatives were denser. If the trend continues in the same manner, we will know less and less about each other. Therefore, we need to eliminate 
obstacles and to move towards each other; for example, let's tackle those border issues.

\section{Nationalism}

Another institution that has hindered the development of a thriving regional world society in Central Asia has certainly been nationalism (Mayall, 1990), or better, 'competitive' or 'adversarial' nationalism associated to an ethnic understanding of sovereignty emphasizing what Elie Kedourie would call 'the excellence of diversity' (1994, p. 44). This has roots in the concept of 'titular nations' as developed during the USSR, when the Autonomous Republics were created on the basis of alleged ethnic uniformity (Tishkov, 1997). Despite several rhetorical appeals to the 'Central Asian people' and to a past of commonality and brotherhood in official discourses at the élite level, especially in bilateral settings and communications, more and more the populations of these states are developing negative, hostile attitudes toward each other, especially in border areas, in the name of a new ethnic-nationalistic idea infused from above by the presidents aiming at substituting the collapsed Soviet ideology with an identity-vacuum filler.

Dividing laws on exclusive and official state languages, discriminations on ethnic and nationality bases, stone-throwing at the border between different villages residents and riots, skirmishes and clashes sparked by nationalistic claims over territory and lands: these problems are indeed acknowledged by state authorities and people themselves, recognising that before becoming sovereign entities, people were simply accustomed to living together side by side, as the concepts of 'Uzbeks', 'Tajiks', 'Kyrgyz', 'Turkmens' and 'Kazakhs' did not even exist (Hierman and Nekbakhtshoev, 2014). In an insightful conversation with a former Kyrgyz diplomat, I was told that 'nationalism and discourses of ethnic differentiation are weakening regional connectivity, 
and this is difficult to accept as historically we have been one people' (2014, personal communication). As Anna Matveeva has aptly noted, 'the factor of ethnicity has grown in significance since early independence,' and communities have come 'to more readily affiliate with their ethnic groups and tend to stereotype the opponent in increasingly ethnic terms' (2017, p. 4).

This fragmentation of a previously more homogeneous human dimension into fractured, often competitive social groups identified with top-down given 'national titularities' reminds us of Matt Weinert's critique of the alleged 'uniformity' of world society, pointing at multiple identities, ideologies, interests and countless 'types' of human beings that have harboured, and harbour, animosity towards others (2015, p. 93).

In this respect, Omelicheva has noted how 'Central Asia, a region of diverse topography, religious practices, and culture with an intricate makeup of multi-layered and mixed identities, exemplifies some of the common patters of national identity construction but also unique manifestations of nationalisms and their impacts on national and regional stability, conflict, regimes and foreign policy among other themes' (2014, p. vii).

The nationalistic projects in the republics are not only undermining the idea of a uniform Central Asian word society, but it is also creating agonistic tensions between previously mixed groups. As Matveeva has observed, 'problems that originally start as mundane village disputes assume a character of ethnic polarization and end in arguments such as "this is our historical land" and "you have no right to be here"” (2017, p. 5).

\section{Market economy/Patrimonial capitalism}

Today more than ever, with the advent of a full-fledged global economy sustained by MNCs, TNAs and technologies that challenge the supposed control of the state over economic activities, 
the concept of world society is inherently associated to economic liberalism and openness (Waever 1992, p. 98; Buzan 2004, p. 19).

The regionalisation of economic world societies in different parts of the world is in fact a proof that economic ties and transnational economic linkages across countries, peoples and professional sectors of societies is more often than not the main driver behind non-state regionalization (East Asia, Latin America). Yet, in Central Asia, a protective, patrimonial and conservative interpretation of the primary institution of the market economy has not allowed for thriving intra-regional contacts and trade. Here, neopatrimonial capitalism is defined as 'a regime where officials become the primary economic actors endowed with power to manipulate with public properties for personal gains' (Rustemova, 2013, pp. 61-62). Other authors speak of 'nomenklatura privatization' (Levi 2007, p. 10).

Rustemova claims that there has been a widely mistaken expectation of the international community with respect to how liberal assumptions in Central Asia, promoting connections via the internet, market values, liberal democratisation, would work in the wake of the transition from a centralized economy to a market-driven one (2013, p. 59). She argues that the reason for this is to be found in how leaders have 'localized' the institution of market economy along patrimonial lines: 'in cases where authoritarian rulers preside over economies with the primary commodity exports, international integration enhances authoritarianism, rather than creating democracy' (2013, p. 60).

In order to enhance state power and to keep a grip on profitable economic assets and resources, Central Asian leaders had to keep in mind that 'integration into the global [and regional] market makes countries more reliant on growing revenues from those [primary commodities] exports, with major economic actors, be it bureaucrats, rulers or investors interested in the political 
stability of the existing regimes as guarantors of their personal well-being' (2013, p. 60), thus hindering and suppressing competition in the domestic and regional market.

As has been argued in a recent study, 'the [Central Asian] governments on whole have been more controlling and protecting rather than orienting towards greater regional connections and facilitating regional trade. The private sector therefore has to raise its voice in helping move up the connectivity agenda' (Kourmanova, 2015, p. 8). Despite the existence of a middle, entrepreneurial class in the states in the region, it is still too weak and pulled towards the regimes' economic orbits to develop sustained cross-border links (Ozcan, 2010).

In such a context, economic groups, communal entrepreneurs and transnational financial actors, despite being nominally members of world society, end up reinforcing the structure of international society being absorbed by it due to mere logics of survival: 'internal economies of scale encourage all groups of people to support the authoritarian regime: investors, local business and ordinary people who remain dependent on the stability of the political regime' (Rustemova, 2013, p. 69).

Yet, it is interesting to consider how this institution of the Central Asian international society affects and interacts with the practice of informal trade at the regional world society level. Kaminski and Mitra aptly grasp this when arguing that informal, shuttle trade between isolated geographies on borders 'is particularly important in supporting the livelihood of border communities, buttressing their prosperity. Furthermore, by strengthening commercial ties, promoting cultural understanding, and deepening community relationships, border trade promotes amicable relations between neighbouring countries' (2012, p. 2), thus forming networks of different non-state actors strongly integrated and overlapping across the region. 
They also notice the 'clash' between interstate and inter-human domains, thanks again to the antagonistic relation between patrimonial capitalism between states and informal trade between peoples in border communities. As a matter of fact, in the region there is the need to take into consideration the "critical impact for good or ill of government interventions that can facilitate or impede border trade by affecting the movement of local people, vehicles, and goods between central Asian countries' (2012, p. 2).

In addition, 'governments deter border trade with requirements for visa and passport stamping that are onerous for border community members in both time and cost, by imposing fees of various kinds, by restricting movements of vehicles and by limiting operating hours of border crossing facilities. Incomplete exemptions from border charges and taxes also significantly impede border trade' (2012, p. 6).

In this passage, quite interestingly, there also visible elements (passports, visas, stamps, cutoms) associated to sovereignty and nationalism, the other two practices hyper-institutionalised dealt with in the previous part of the paper.

Yet, despite these institutional clashes, bazaars and informal trade are a vivid sign of a Central Asian society sizzling informally and under the cloak of rigid, controlling state practices. Far from being an outdated, pre-modern economic practice, as an orientalist approach would maintain, 'bazaars are modern institutions with critical economic and political roles' (Ozcan 2010, p. 119), entrenching connectivity and a sense of communal 'we-ness' that is tamed by more formal arrangements devised by regional states.

This leads to the next and final section of the paper, where the character of the Central Asian world society, despite the hurdles identified above, shows signs of dynamism and life. 


\section{E pur si muove! ${ }^{10}$}

To say that inter-state dynamics based on the hyper-institutionalization of sovereignty, nationalism and patrimonial capitalism have completely suppressed the development of a world society in Central Asia would certainly be an overstatement. What can certainly be said with respect to this is that several dynamics at the level of world society in Central Asia have assumed an informal, weak character, but are nonetheless existing. In the words of the Kyrgyz political analyst Sheradil Baktygulov, world society in Central Asia is like a submarine: it is there but not observable (2012). In Wittgensteinian terms, it can be said that there is a family resemblance to a Central Asian world society, thanks to language, shuttle trade, tribes, clans and groups, connections between criminals and mafias, even food, festivities and traditions, but, again, the hyper-institutionalisation of sovereignty, nationalism and patrimonial capitalism is taming the clear perception and operation of it.

To begin with, elements pertaining to the 'world society' dimension in Central Asia are very much present in the inter-state political lexicon in the region. For example, if one looks at how the presidents relate to each other, 'it is possible to see how diplomacy in Central Asia works like in bazaars' (Kyrgyz analyst, personal communication, 2014; former Kyrgyz diplomat, 2014, personal communication), ${ }^{11}$ the importance of which has been noted above, while a common metaphor to explain how international relations work in the region is that of mahalla, the autonomous social institution built around familial ties and Islamic rituals especially in Uzbekistan, Tajikistan and Kyrgyzstan (diplomat, 2014, personal communication).

Furthermore, in a lengthy interview dating February 2011, the leader of Uzbekistan's opposition Erk party, Muhammad Solih, illustrated quite aptly how the world society aspect that 
was perceived in the 1990s, as reviewed in the previous section, has not yet completely disappeared from the region:

We, Uzbeks, do not consider the Kazakh, Kyrgyz, Turkmen and Tajik communities residing on the territory of our motherland to be diasporas. They are our brothers and Uzbekistan is their motherland too, because similarly to Uzbeks, they have been living on our soil since the beginning of times. Similarly, the Uzbek communities residing in Kazakhstan, Kyrgyzstan, Tajikistan and Turkmenistan are not diasporas in those countries either, because the Uzbeks, too, have been residing there for centuries. Our peoples should not bear responsibility for the Stalinist policy of the artificial disengagement of Turkestan. Diaspora is an insulting term for our peoples. Those who use it in relation to their brothers, living side by side, are narrow-minded people who have forgot the history of their own ancestors (BBC Worldwide Monitoring 2011).

In recent years, contacts between people across the Central Asian states have been rising, according to several interviewees from the region. Public diplomacy, with the help of community-based delegations working with official ones, is cooling down conflicts in border areas (Uzbek diplomat, 2014, personal communication); student exchanges between Central Asian universities to promote bottom-up regional understanding and awareness are now more popular, and recognition of mutual diplomas is underpinning this trend (representative of a Central Asian university, 2014, personal communication); roundtables, conferences and meetings between scholars and young diplomats 
are now more frequent, even if participation of representatives from Turkmenistan and Uzbekistan is still somehow limited (Central Asian scholar, 2014, personal communication).

Finally, platforms for regional news and for knowledge of regional issues are indeed being developed. Virtual information spaces detached from the governments of the region such as CANews, Akipress, UZMetronom, Asia Plus and Avesta, to name a few, all have tabs called 'Central Asia' where news from all the five regional states are presented and discussed (in UZMetronom the specific regional section is tellingly called 'bratya', Russian for 'brotherhood').

\section{Conclusions}

This paper has been an incipient investigation on the relationship between international and world society in Central Asia. Following the recent 'regionalization' of the ES, I tried to uncover the regional aspect of world society focusing on Central Asia, showing a 'race to diversity' but at the same time recognition of common blood, culture and history in different discourses.

Initial and tentative research shows that international and world society can be complementary as well as antagonistic, especially when the stability of the former depends, in the minds of state leaders, on taming the latter. The hyper-institutionalization of sovereignty, nationalism and patrimonial capitalism has reduced the interactions between the interstate and the interhuman domains of the region. In the words of an Uzbek diplomat, 'it is as if Central Asia was a dual society. There is a legal, political one, based on sovereign states, and a cultural one. In the region it is not like in the West, where you don't know your neighbour. We all know each other, we reject individuality. There is a sense of openness, it is difficult to accept "separational" institutions such as sovereignty and borders' (2013, personal communication). 
The Central Asian case raises interesting theoretical questions: to what extent the flourishing of world society is compatible with an authoritarian international society? Is it possible, conceptually speaking, to speak of a world society of autocrats? Another implication that this case study has for wider ES theorizing is that of considering informal institutions and practices that can well exist at the level of regional world societies (Helmke and Levitsky, 2012).

The case of Central Asia, especially in the economic dimension, shows that the regional world society has resorted to ancient informal practices to sustain itself against the hyperinstitutionalisation of state- and regime-centred economic practices. This finding emphasizes how the interstate and the interhuman domains can be normatively at odds, with the latter being in a subaltern position and engaging in practices of resistance and distinctiveness making 'regional world politics' thriving and sizzling (Williams, 2015, pp. 124-135).

The value of this paper, I believe, lies in promoting a comparative agenda of different social domains and institutions in ES theory to promote a truly comprehensive analysis of societal relations among state and non-state actors in different regional international societies, incorporating concepts and research form sociology, anthropology, religion and area studies. By means of conclusions, I would like to go back to the detachment of Central Asian international society from its world society component. Nowadays,

'[due to the governments' actions], cultural and religious identity does not work in Central Asia. People are as far from one another as heaven and earth. However, the horizon is connecting heaven and earth. The horizon demonstrates the possibility of the unification of two different elements. $[\ldots]$ The interests of the Central Asian region require the revival of basic 
human values. Perhaps, it is time for the start of reforms in the minds of

people' (Baktygulov, 2012).

Whether the international society in the region will allow for these reforms and for a more

prominent role, in regional politics, of a strongly intertwined community of human beings dating

back to centuries, is yet to be seen.

\section{Notes}

${ }^{1}$ BBC Summary of World Broadcasts, 8 July, 1990.

${ }^{2}$ Slovo Kyrgyzstana, 7 January, 1993, 'Tashkent porodil dobrye nadezhdy chuvstvuya lokot' drug druga'.

${ }^{3}$ Slovo Kyrgyzstana, 22 January, 1993, 'A. Akaev: "Sudya po itogam goda zhizni Sodruzhestva, ono nichevo konstruktivnovo uzhe ne mozhet dat'...nado izmenit' evo formu".

${ }^{4}$ Slovo Kyrgyzstana, 30 March, 1993, 'Aralskoe more - Obsh'aya beda'.

${ }^{5}$ Slovo Kyrgyzstana, 31 October - 1 November, 1995, 'Kak podelit'granitsami dushi narodov?'.

${ }^{6}$ Slovo Kyrgyzstana, 18-19 July, 1997, 'Tsentral'naya Aziya - zemlya mira, soglasiya i tolerantnosti: vzglyad iz Kyrgyzstana'.

${ }^{7}$ Slovo Kyrgyzstana, 30 November, 1999, 'My - Tsentral'noaziaty: Gotovy li zhit' v soglasii v XXI veke?'.

8 'Eurasianism' was another competing narrative at that time. Yet, 'Eurasianism' was more elite-driven that peopledriven, as President Nazarbayev was the main proposer of it. Also, during my fieldwork, references to 'Turkestan' and 'Central Asia' were by far more numerous than those to 'Eurasia'.

${ }^{9}$ A recent paper produced by Alexey Krasin (2014, available at http://ipp.kg/en/2910-2/) with the technical support of the British Embassy in Bishkek has indeed stressed how order in the region has been far better maintained by state repressive institutions and power rather by than local non-state actors and local communities founded on old communal principles.

10 'And yet it moves!'. This sentence is attributed to Galileo Galilei, the famous Italian astronomer and mathematician, when defending his theory of heliocentrism in front of the Inquisition Tribunal.

${ }^{11} \mathrm{My}$ interviewees argued that for Central Asian states 'dealing with each other is very much a matter of trade, like in a bazaar. You go there, you want to buy something, you propose a price he says his price, you propose something less, and then you meet halfway.'

\section{References}

Abdullaev, E. (2002) The Central Asian Nexus: Islam and Politics. In B. Rumer (ed.) Central Asia: A Gathering Storm? London: ME Sharpe.

Abdyldaev, E. (2008) Comment at the roundtable 'Kazakhstan - Kyrgyzstan: state and perspectives of a strategic partnership’. Bishkek, Kyrgyzstan, 26 June.

Amineh, M.P. and Houweling, H. (2005) Central Eurasia in global politics. Leiden, Brill. 
Baktygulov, S. (2012) Central Asia: The Submarine Effect. 2 April, http://www.ipp.kg/en/news/2303/, accessed 20 October 2016.

BBC Worldwide Monitoring (2011) Exiled opposition leader warns of social 'outburst' in Uzbekistan. 17 February. Accessed via LexisNexis, 20 October 2016.

Benvenisti, E. (2008) Asian Traditions and Contemporary International Law on the Management of Natural Resources. Chinese Journal of International Law 7(2): 273-283.

Bull, H. (1977) The Anarchical Society. London, Palgrave Macmillan.

Burnashev, R. (2002) Regional Security in Central Asia: Military Aspects. In B. Rumer (ed.) Central Asia: a gathering storm? London: ME Sharpe.

Buzan, B. (2004) From International to World Society? English School Theory and the Social Structure of Globalisation. Cambridge: Cambridge University Press.

Clark, I. (2007) International Legitimacy and World Society. Oxford: Oxford University Press.

Collins, K. (2006) Clan politics and regime transition in Central Asia. Cambridge: Cambridge University Press.

Costa-Buranelli, F. (2014) XIX-century Central Asia as an international society. ISA Annual General Meeting. Toronto, ON, Canada.

Costa-Buranelli, F. (2015) International Society and Central Asia. PhD Thesis, King's College London, London, UK.

Cummings, S.N. (2012) Understanding Central Asia: Politics and Contested Transformations. London: Routledge.

Cummings, S. N. and Hinnebusch, R. (eds.) (2011) Sovereignty after the Empire: Comparing the Middle East and Central Asia. Edinburgh: Edinburgh University Press.

Dadabaev, T. (2012) Securing Central Asian Frontiers: Institutionalisation of Borders and Interstate Relations. Strategic Analysis, 36(4): 554-568.

Gleason, G. (2001) Foreign Policy and Domestic Reform in Central Asia. Central Asian Survey 20(2): 167-182.

Goble, P. (1990) Central Asians form political bloc. Report on USSR: 18-20, 13 July.

Helmke, G. and Levitsky, S. (2004) 'Informal institutions and comparative politics: A research agenda.' Perspectives on politics 2(4): 725-740. 
Hierman, B. and Nekbakhtshoev, N. (2014) Whose Land Is It? Land Reform, Minorities, and the Titular "Nation" in Kazakhstan, Kyrgyzstan, and Tajikistan. Nationalities Papers 42(2): 336-354.

Kaminski, B. and Mitra, S. (2012) Borderless Bazaars and Regional Integration in Central Asia: Emerging Patterns of Trade and Cross-Border Cooperation. Washington: World Bank Publications.

Kavalski, E. (2012) Central Asia and the Rise of Normative Powers: Contextualizing the Security Governance of the European Union, China, and India. New York: Bloomsbury Publishing.

Kedourie, E. (1994) Nationalism. Oxford: Blackwell.

Kourmanova, A. (2015) Connecting Entrepreneurs in Central Asia. Central Asia Policy Brief No. 30, November 2015.

Kuzmits, B. (2013) Borders and Orders in Central Asia. Baden-Baden: Nomos.

Levi, S. (2007) Turks and Tajiks in Central Asian History. In J. Sahadeo and R. Zanca (eds.) Everyday Life in Central Asia. Bloomington: Indiana University Press.

Lewis, D. (2008) The Temptations of Tyranny in Central Asia. New York: Columbia University Press.

Mandelbaum, M. (1994) Introduction. In M. Mandelbaum (ed.) Central Asia and the World. New York: Council of Foreign Relations Press.

Matveeva, A. (2017) Divided we fall... or rise? Tajikistan-Kyrgyzstan border dilemma, Cambridge Journal of Eurasian Studies 1: 1-20.

Mayall, J. (1990) Nationalism and international society. Cambridge: Cambridge University Press.

Olcott, M. B. (1994) The Myth of Tsentral'naya Aziia. Orbis 38: 549-565.

Omelicheva, M. (2014) Nationalism and Identity Construction in Central Asia: Dimensions, Dynamics, and Directions. New York: Lexington Books.

Ozcan, G. B. (2010) Building states and Markets - Enterprise Development in Central Asia. Houndmills: Palgrave Macmillan.

Pella, J.A. (2013) Thinking Outside International Society: A Discussion of the Possibilities for English School Conceptions of World Society. Millennium: Journal of International Studies 42(1): 65-77.

Polat, N. (2002) Boundary Issues in Central Asia. Ardsley: Transnational Pub. Incorporated. 
Pomfret, R. (2010) Central Asia after two decades of independence. Working Paper, United Nations University, World Institute for Development Economics Research.

Rahimov, M. (2007) From Soviet republics to independent countries: challenges of transition in Central Asia. Perspectives on Global Development and Technology. 6(1): 291-312.

Reeves, M. (2014) Border Work: Spatial Lives of the State in Rural Central Asia. New York: Cornell University Press.

RFERL (2016) Majlis Podcast: Mapping Conflict Along Ferghana Valley's Borders. 3 April, http://www.rferl.org/a/majlis-podcast-mapping-conflict-along-ferghana-valleyborders/27651487.html, accessed 4 November 2016.

Rustemova, A. (2013) Rent-Seeking and Authoritarian Consolidation in Kazakhstan and Uzbekistan. In M.E. Aleprete and R. Vanderhill (eds.) International Dimensions of Authoritarian Persistence: Lessons from Post-Soviet States. New York: Lexington Press.

Sahadeo, J. and Zanca, R. (eds.) (2007) Everyday Life in Central Asia. Bloomington: Indiana University Press.

Syroejkin, K. (2008) Comment at the roundtable 'Kazakhstan-Kyrgyzstan: state and perspectives of a strategic partnership’. Bishkek, Kyrgyzstan, 26 June.

Tishkov, V. (1997) Ethnicity, Nationalism and Conflict in and after the Soviet Union: the Mind Aflame. London: Sage.

Tolipov, F. (2007) Geopolitical Aspects of the Problem of Regional Integration in Central Asia. Kyrgyzstan Brief, Institute for Public Policy, Issue 9 - March/April.

Tolipov, F. (2015) Micro-geopolitical semiotics of Central Asia: 'Crossroads' and 'bridges'. Central Asia and the Caucasus 16(2): 35-42.

Vincent, R.J. (1987) Human Rights and International Relations. Cambridge: Cambridge University Press.

Volovoj, V. (2009) Problems and Fundamentals of Stability in Central Asia. Lithuanian Foreign Policy Review 22: 99-129.

Waever, O. (1992) International Society - Theoretical Promises Unfulfilled? Cooperation and Conflict 27(1): 97-128.

Wight, M. (1966) Diplomatic Investigations: Essays in the Theory of International Politics. London: Allen \& Unwin.

Wight, M. (1991) International Theory: The Three Traditions. Leicester: Leicester University Press. 
Williams, J. (2002) Territorial borders, toleration and the English School. Review of International Studies 28(4): 737-758.

Williams, J. (2005) Pluralism, Solidarism and the Emergence of World Society in English School Theory. International Relations 19(1): 19-38.

Williams, J. (2015) Ethics, Diversity and World Politics. Oxford: Oxford University Press. 